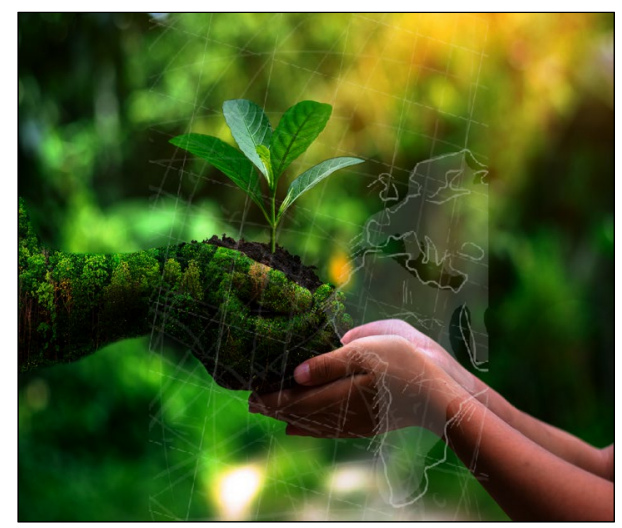

\title{
TRANSFORMATIVE LEAPFROGGING TO A WELLBEING ECONOMY IN AFRICA
}

\author{
Desta Mebratu
}

\section{Introduction}

2015 was a year during which a broader global consensus was reached across science, politics and morality on the need for transformational change. The adoption of Agenda 2030 on Sustainable Development Goals (SDGs) and the Paris Declaration on Climate Change together with the Encyclical issued by Pope Francis on climate change, which happened during the same year, represents this development. In essence, all these and other declarations recognised the urgency for the transition to inclusive, low-carbon and resource-efficient economies at the global level. The declarations underline that such a transformation is critical if humanity was to avoid an irreversible natural disaster of a global scale and make progress towards a more inclusive society. The path to be followed by each country and regions could be different from one to the other. This is because each path is dependent on the current level of development and the specific socio-economic and socio-ecological challenges faced by the respective countries and regions. Broadly categorised, countries with developed economies would require to deconstruct 
and retrofit their existing infrastructural base while countries that are at an early stage of development have the opportunity to build their infrastructure on a more inclusive, low-carbon and resource-efficient basis. By doing so, they maximise their leapfrogging opportunity into a more sustainable development trajectory.

Besides what has been agreed at a global level, Africa as a region developed its own Agenda 2063 that aims to transform the development visions and aspirations of its people into reality and improve the wellbeing of its people. Many African countries have been developing ambitious development visions and strategies that align with Agenda 2030 and Agenda 2063. However, most of these countries are facing severe challenges in making progress in implementing their visions and strategies. Much of these challenges are associated with the fact that most of these national efforts are locked in the conventional economic development models of the twentieth century that has some fundamental limitations. In light of the early stage of development of most African countries, the region is believed to have the largest leapfrogging potential to an economy that is inclusive, climate-resilient and resource-efficient. Putting Africa on a more sustainable development trajectory is a global opportunity that should not be missed by the international community.

This chapter provides an overall conceptual framework for transformative leapfrogging of African economies and presents the key drivers and elements of such leapfrogging opportunities. The chapter starts with a brief discussion of the conceptual basis for the transition to an inclusive, low-carbon and resource-efficient economy and critical aspects of leapfrogging including the qualitative distinction between incidental and transformative leapfrogging. This is followed by a section that highlights the key drivers that favour transformative leapfrogging in Africa and the related constraints that need to be addressed by African countries.

\section{Environment and economic development}

For millennia, the interaction between human society and its natural environment had been primarily governed by adherence to the limits and correcting conditions imposed by the natural systems. This relationship started to change with the onset of the agricultural revolution and subsequently took a new proportion with the industrial revolution. While these changes were initially driven mainly by the Judeo-Christian beliefs of 'man's right to master the earth', it was later given an economic rationale of wealth creation for economic development. This subsection provides an overview of the perceived dichotomy between economic growth and the environment followed by a synoptic review of the concept of sustainability and sustainable development. 


\section{Economic growth and environment}

One of the major myths that have adversely affected progress in sustainable development policy-making is the perceived dichotomy between the environment and the economy that is dominant in neo-classical economics. This resulted in continuous depletion and degradation of the natural ecosystem as a consequence of externalising all costs associated with environmental inputs and services. The concept of the environmental Kuznets curve (EKC), which became popular in the 1990s, attempted to describe the relationship between economic growth and environmental pollution by applying Kuznets' theory. The Kuznets curve, which is an inverted U-shaped curve, is based on the hypothesis that was first advanced by economist Simon Kuznets stating that as an economy develops, market forces first increase and then decrease economic inequality (Munasinghe, 1999). According to the environmental Kuznets curve hypothesis, economic growth increases environmental pressures at early stages of development, but after a turning point, high per capita income levels enable societies to reduce their ecological impact (Padilla, 2017). In a nutshell, EKC states that indicators of environmental degradation tend to get worse as new economic growth occurs until average income reaches a certain point over the course of development (Shafik, 1994).

The World Bank's World Development Report 1992 (International Bank for Reconstruction and Development [IBRD], 1992) argued that as incomes rise, the demand for improvements in environmental quality will increase resulting in more resources being made available for environmental investment. The assertion is that once countries reach a certain level of growth, they will be in a position to invest in environmental protection measures, which will result in improved environmental quality. This has been a mantra that has been fiercely advocated by some international development organisations and development experts in the last decade of the twentieth century. Even if the overall assertion of the EKC might have been correct for some developed countries concerning limited types of environmental pollution, it cannot work ad infinitum for all countries. Besides the various econometric limitations outlined by Stern (2003), the foundation of EKC became more discredited in the last couple of decades, mainly for the following reasons:

As was concluded by many international scientific panels, the existing global economic system has already overshot the carrying and assimilating capacity of the planetary system in several areas. This places an ecological limit to the industrialisation of developing countries' economies following the same old path of industrialisation. 
Significant progress has been made in developing more resource-efficient and environmentally-sound technologies across sectors since the 1990s. This created opportunities for newly industrialising countries to develop their economy in a more economically and ecologically efficient way. These opportunities led to the possibility of tunnelling through the environmental Kuznets curve and achieving economic growth with reduced environmental impacts.

The long-standing dichotomy between environment and economic development, which has been misguiding policy development in most countries, has been debunked in the subsequent decades. This has resulted in global consensus documents aimed at promoting alternative development pathways that meet the multiple economic, social and environmental objectives of a country.

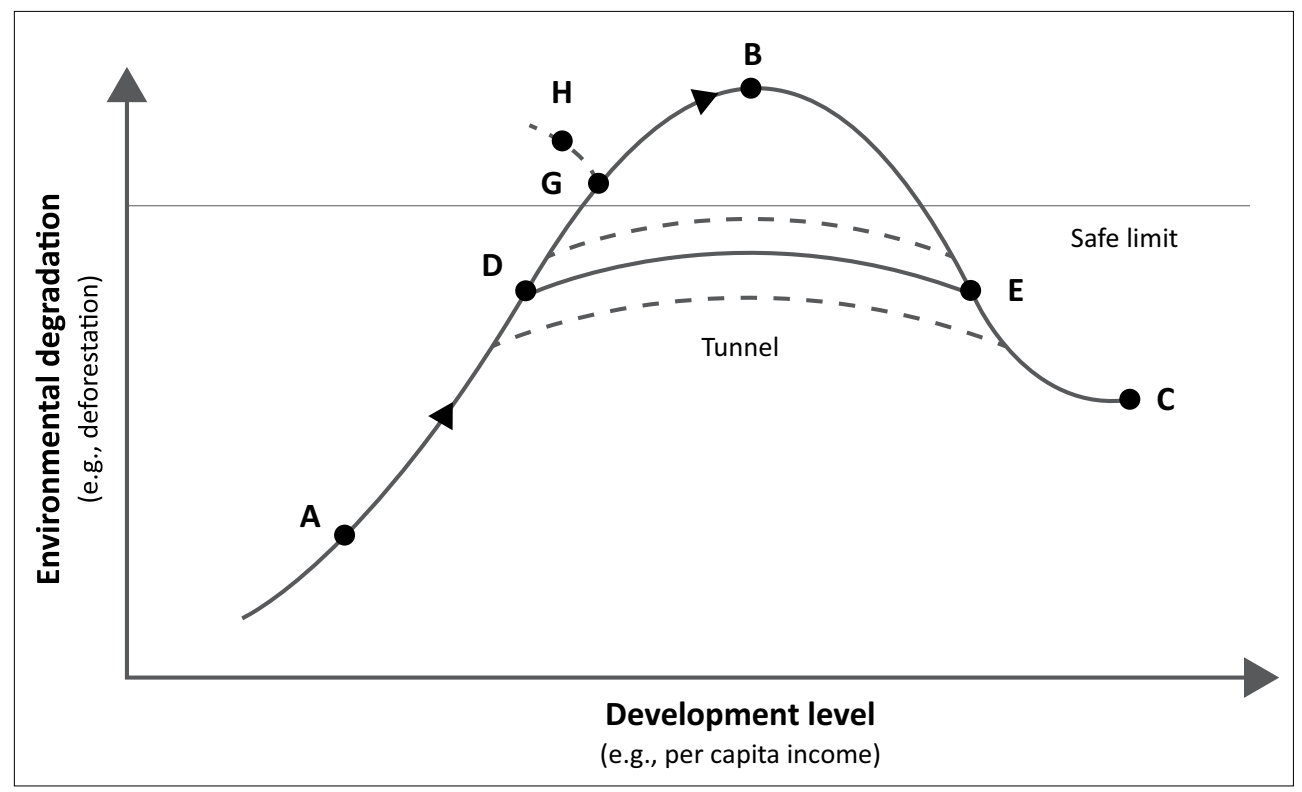

Figure 1.1 Tunnelling through the environmental Kuznets curve using sustainable development strategies (Source: Munasinghe, 1999:95)

All African countries have signed up to the most recent global sustainable development consensus documents including Agenda 2030 on Sustainable Development Goals and the Paris Declaration on Climate Change. Despite their full endorsement of these documents, many African countries are still trapped in the idea of 'industrialise first and deal with the environment later'. The first major step to getting ready for the opportunities from transformative leapfrogging is to get rid of such an obsolete notion of industrialisation which does not fit well with the reality of the twenty-first century. 


\section{Sustainability and sustainable development}

Major social transformation processes have shaped human history over millennia. These transformational processes determined the critical features of socioeconomic relationships both within communities and across nations. However, they also fundamentally redefined our relationship with the natural environment. Two of the most significant social transformations are the agricultural and industrial transformations, which radically redefined human society. Both of these transitions were driven by confluences of crisis which include the environmental crisis of various dimensions. The dynamic relationship between society and its natural environment had been one of the critical drivers of these social transformations while their outcomes had also redefined it. The agricultural transformation, as a successful response to wildlife scarcity faced by the hunter-gatherer society, resulted in slow population growth from about 10 million to approximately 800 million by 1750 (Meadows, Meadows \& Randers, 1992). This created new scarcities and social conflict, especially in land and energy, which led to the industrial revolution that began in England with the substitution of abundant coal for vanishing biomass resulting in the introduction of the steam engine.

Compared to previous centuries, the twentieth century had been a period of unprecedented economic growth and development driven by a faster pace of industrialisation and globalisation. However, it was also a century that saw exponential growth in the volume of resource extracted from the natural environment and the related environmental degradation. The International Resource Panel (IRP) reported that over the past five decades, our global population has doubled, the extraction of materials has tripled and the gross domestic product (GDP) has quadrupled. The report further concluded that the extraction and processing of natural resources have accelerated over the last two decades, and accounts for more than 90 percent of our biodiversity loss and water stress and approximately half of our climate change impacts (IRP, 2019). On the other hand, the International Panel on Climate Change (IPCC) concluded that if humanity is to avoid irreversible change, it has to limit global warming to $2^{\circ} \mathrm{C}$ relative to the period $1861-1880$ and reach carbon neutrality by the second half of this century (IPCC, 2014). French economist Thomas Piketty maintains that on the social front, while social inequality seemed to narrow down in developed countries in the decades immediately after the Second World War, it became significantly wide across the world with the increased globalisation of national economies (Piketty, 2014).

The relationship and interaction between the natural environment and society have been a subject of discourse for thousands of years, be it in philosophy or religion. However, it took a different scope and dimensions since the middle 
of the twentieth century due to the global proportion of the environmental impacts that were being faced by humanity. In this context, it has been more than 30 years since the terms 'sustainability' and 'sustainable development' rose to the prominence in international development discourse. Although the terms are more recent terminologies, there are important schools of thoughts that are considered as historical precursors to the current discourse (Mebratu, 1998). This ranges from the traditional conceptualisation of 'living in harmony with nature' adhered to by indigenous communities across the world, to the various religions which represented the 'voice of nature to humanity' by celebrating and consecrating our ties with the non-human world (Gottlieb, 1996). The relative vagueness of the concept coupled with its increasing importance in national and international policies led to the proliferation of definitions and interpretations that emphasise one or the other aspect of sustainability and sustainable development (Mebratu, 1998).

Over the subsequent decades, numerous processes were initiated from global to local levels focussing on different aspects of sustainability and sustainable development. As a result of these initiatives and processes, our knowledge and understanding of the natural environment and its interaction with our socioeconomic systems have significantly expanded. Despite the progress made so far, we have not been able to go beyond incremental gains which have limited capacity to contain and reverse the unsustainable momentum that is building up. This is manifested through the deepening socio-economic and social-ecological crisis expressed in the form of growing environmental degradation, persistent economic stagnation, increasing unemployment and growing disparities between and within countries. These and other global and regional developments have brought the transition to inclusive, low-carbon and resource-efficient economies to the centre of national and international development discourse.

Swilling and Annecke (2012) argue that sustainability is a challenge that is difficult to comprehend through disciplinary lenses and the significance of complexity theory lies in the fact that it shows how to make this break from reductionism. Applying principles of systems dynamics based on key principles of systems thinking could help us to better understand sustainability as an organising principle of any system. Mebratu (2000) proposed a planetary sustainability matrix aimed at highlighting the hierarchical relationships and interactions between the different dimensions of the cosmic universe as presented in the sustainability matrix shown in Table 1.1. 
Table 1.1 The planetary sustainability matrix

\begin{tabular}{|l|l|l|l|l|l|}
\hline $\begin{array}{l}\text { Planetary } \\
\text { sphere/ } \\
\text { hierarchy }\end{array}$ & $\begin{array}{l}\text { Subsidiary } \\
\text { process }\end{array}$ & $\begin{array}{l}\text { Measurable } \\
\text { flows }\end{array}$ & $\begin{array}{l}\text { Regulating } \\
\text { mechanisms }\end{array}$ & $\begin{array}{l}\text { Non-stable } \\
\text { scenarios }\end{array}$ & $\begin{array}{l}\text { Default } \\
\text { corrections }\end{array}$ \\
\hline $\begin{array}{l}\text { Abiotic } \\
\text { satural }\end{array}$ & $\begin{array}{l}\text { Geophysical } \\
\text { assimilation and } \\
\text { accumulation }\end{array}$ & $\begin{array}{l}\text { Mass and } \\
\text { energy flow }\end{array}$ & $\begin{array}{l}\text { Geological } \\
\text { cycles and } \\
\text { processes }\end{array}$ & $\begin{array}{l}\text { Disturbances } \\
\text { of cycles and } \\
\text { variations }\end{array}$ & $\begin{array}{l}\text { Natural } \\
\text { calamities and } \\
\text { disasters }\end{array}$ \\
\hline $\begin{array}{l}\text { Biotic } \\
\text { natural } \\
\text { system }\end{array}$ & $\begin{array}{l}\text { Reproduction } \\
\text { and metabolic } \\
\text { processes }\end{array}$ & $\begin{array}{l}\text { Population and } \\
\text { consumption }\end{array}$ & $\begin{array}{l}\text { Mobility and } \\
\text { succession }\end{array}$ & $\begin{array}{l}\text { Persistent } \\
\text { overshoots } \\
\text { and migration }\end{array}$ & $\begin{array}{l}\text { Population crash } \\
\text { or extinction }\end{array}$ \\
\hline Social & $\begin{array}{l}\text { Family and social } \\
\text { network creation }\end{array}$ & $\begin{array}{l}\text { Resource } \\
\text { distribution and } \\
\text { wellbeing }\end{array}$ & $\begin{array}{l}\text { Social norms, } \\
\text { policies and } \\
\text { regulations }\end{array}$ & $\begin{array}{l}\text { Conflicts and } \\
\text { social unrest }\end{array}$ & $\begin{array}{l}\text { Revolution } \\
\text { and war }\end{array}$ \\
\hline Economic & $\begin{array}{l}\text { Value addition } \\
\text { and surplus } \\
\text { exchange }\end{array}$ & $\begin{array}{l}\text { Resource and } \\
\text { information flows }\end{array}$ & $\begin{array}{l}\text { Market } \\
\text { mechanisms }\end{array}$ & $\begin{array}{l}\text { Economic } \\
\text { recession }\end{array}$ & $\begin{array}{l}\text { Economic } \\
\text { depression } \\
\text { and collapse }\end{array}$ \\
\hline
\end{tabular}

(Source: Adapted from Mebratu, 2000:67)

The horizontal axis of the sustainability matrix consists of the subsidiary process, measurable flows, regulating mechanisms, non-stable scenarios and default corrections while the vertical axis represents the hierarchical spheres of our planetary universe. The subsidiary processes are those processes that inherently determine stability within the planetary regimes while the measurable flows are the characteristic flows (of energy, material and information) that help to describe the planetary entity. The regulating mechanisms are the mechanisms which determine its functional stability. The non-stable scenarios are indicators of effects of persistent offshoots of the measurable parameters, while the default corrections are the systemic corrective mechanisms that restore the stability of the system.

In this context, social transformations are systemic responses that are necessitated by the dynamic interaction between the socio-ecological and socio-economic factors of a given society. The specific scope and nature of the transformation process shall be determined by the particular dynamics of the socio-economic and socio-ecological interactions. Such social transformation could happen either through a smart and creative response to non-stable scenarios or as an outcome of the default corrections of the system which will be beyond anybody's control. The stark choice that humanity is faced with today is whether it will act timely and take the necessary action to bring about a desirable social transformation outcome or be at the receiving end of the default corrective action by the system, which would have its undesirable consequences.

As noted by Swilling and Annecke (2012), the evolution of new modes of existences instigated by innovations that partially or provisionally resolved the crisis and destroyed the basis for pre-existing modes of operations, technologies and hierarchies of power were crucial prerequisites for social transformations. 
All major socio-economic transformations are characterised by changes that happened in leaps and bounds. The transformational impact we see with the exponential developments in the field of information and communication technology (ICT), including the application of artificial intelligence, and the progress made on renewable energy development are some of the critical factors that determine the nature and pace of the transition in the coming decades. In a nutshell, we live in an era that provides numerous transformative leapfrogging opportunities towards a society that is more inclusive, low-carbon and resourceefficient. This is particularly true for most African countries at the early stage of industrial development since they have a higher opportunity to build their economy on a more sustainable basis.

\section{Leapfrogging and social transformations}

Moments of social transformation in human history are mainly characterised by the various tensions between the old and dominant system that strives to maintain the status quo and the new system that emerges as a result of the system dynamics. These tensions are usually resolved with the new techno-economic system taking the upper hand by meeting the required threshold of transformational change. In the next section, we look at the key features of lock-in and leapfrogging followed by the distinction between incidental leapfrogging and transformative leapfrogging supported with some case studies. The last subsection covers some of the key drivers and factors of transformative leapfrogging.

\section{The concept of lock-in and leapfrogging}

From a technological progress perspective, the dynamics between lock-in and leapfrogging scenarios has been central to all forms of social transformations, including the agricultural and industrial transformations. These dynamics become even more critical for the transition to inclusive, low-carbon and resource-efficient economies given the dominant role of technology in today's economies. Hence, it will be essential to understanding the relationship and distinction between these two critical factors of technological transition. Corvellec, Campos and Zapata (2012) note that the notion of lock-in originates from historical studies of science and technology. The idea of path-dependence (Corvellec et al., 2012; Liebowitz \& Margolis, 1995; Schreyögg \& Sydow, 2010) is close to the notion of lock-in. Both ideas underscore that today's solutions are constrained by yesterday's choices and decisions even if these choices have lost their relevance and new alternatives have emerged that are more efficient and effective than the solutions that currently dominate. However, there are some distinctions in the sense that while pathdependence focuses on the constraints that the past puts on present decisions, lock-in describes a current state of things (Corvellec et al., 2012). Once it is set, 
it is not easy to break-up a lock-in due to stiff resistance for any change that will be created by the coalitions of interested groups and forces that benefit from the status quo.

However, as suggested by Cowan and Hulten (1996), possibilities of unlocking technologies can emerge from a combination of events, just as the process of lock-in can start with a small historical event or sequence of events. Grabher (1993) identifies three types of lock-in. These are: (i) functional, as in the case of personal ties and joint investment; (ii) cognitive, because of common ways of interpreting or envisioning things; (iii) and political, through associations or coalitions of industrialists or politicians. Corvellec et al. (2012) identified four types of rationales for a given state of infrastructural lock-in, taking the lock-in effect of waste incineration infrastructure as a basis. These are: (i) institutional rationale that are determined by existing policy and institutional frameworks; (ii) technical rationale justified through economic and technological factors that create a stalemate on identifying and accepting a new alternative; (iii) cultural rationale that leads to the establishment of a culture-bound cognitive lock-in; and (iv) material rationale associated with the physical infrastructure and related resource flow which may require a radical redesign of this network.

The concept of leapfrogging was initially used in the context of economic growth theories and industrial-organisation innovation studies with a specific focus on competition among firms. In the field of industrial organisation (IO), the leading work on leapfrogging was developed by Fudenberg, Gilbert, Stiglitz and Tirole (1983) who analysed the conditions under which a new entrant can leapfrog an established firm. However, Joseph Schumpeter's notion of 'gales of creative destruction' (Schumpeter, 1942) provided the conceptual foundation for this and other subsequent works on innovation and leapfrogging. Schumpeter proposed that companies holding monopolies based on incumbent technologies have less incentive to innovate than potential rivals, and therefore they eventually lose their technological leadership role when new radical technological innovations are adopted by new firms which are ready to take risks (Schumpeter, 1942). According to Schumpeter, the gale of creative destruction describes the process of industrial mutation that incessantly revolutionises the economic structure from within, steadily destroying the old one, creating a new one (1942, cited in Tirole, 1988). The concept of creative destruction as defined by Schumpeter became a powerful concept in the field of economic research because it can explain many of the dynamics or kinetics of industrial change: the transition from a competitive to a monopolistic market, and back again (Sidak \& Teece, 2009). Nelson and Nelson (2002) noted that it has also been the inspiration of endogenous growth theory and evolutionary economics. 
Table 1.2 has been developed building upon the classification of the rationales for lock-in described earlier to further clarify the similarity and distinction between technological and infrastructural lock-in and leapfrogging.

Table 1.2 Comparison of the rationales of lock-in and leapfrogging

\begin{tabular}{|l|l|l|}
\hline The rationale & Lock-in & Leapfrogging \\
\hline Temporal & $\begin{array}{l}\text { Managing the present within the } \\
\text { boundaries and constraints of the past }\end{array}$ & $\begin{array}{l}\text { Creating a new future by breaking out of the } \\
\text { boundaries and constraints of the present }\end{array}$ \\
\hline Institutional & $\begin{array}{l}\text { Viability of the status quo under existing } \\
\text { policies, regulations and institutional } \\
\text { procedures }\end{array}$ & $\begin{array}{l}\text { More economical, social, and environmental } \\
\text { benefits could be achieved }\end{array}$ \\
\hline Technical & $\begin{array}{l}\text { Focus on incremental efficiency gain within } \\
\text { a piecemeal and stand-alone operational } \\
\text { objective }\end{array}$ & $\begin{array}{l}\text { Drive for systems-wide transformational } \\
\text { outcomes by redefining the operational } \\
\text { boundaries }\end{array}$ \\
\hline $\begin{array}{l}\text { Cognitive and institutional inertia caused } \\
\text { by fear of the unknown }\end{array}$ & $\begin{array}{l}\text { Preparedness to be innovative and disruptive } \\
\text { with focus on higher and broader outcomes }\end{array}$ \\
\hline $\begin{array}{l}\text { Rehabilitating and retrofitting of existing } \\
\text { physical infrastructure with an emphasis on } \\
\text { optimising resource flow }\end{array}$ & $\begin{array}{l}\text { Deconstructing and replacing existing } \\
\text { physical infrastructure with a new } \\
\text { infrastructure of a higher metabolic function }\end{array}$ \\
\hline
\end{tabular}

As the table shows, concerning the time dimension, a lock-in situation is more focused on managing the present within the boundaries and constraints of the past while the leapfrog scenario focusses on creating a new future by breaking out of the boundaries and constraints of the present. At the institutional level, the lock-in scenario strives to ensure and secure the viability of the status quo under existing policies, regulations and institutional procedures while the leapfrog scenario aims at breaking the dominant institutional framework with a focus on creating multiple economic, social, and environmental benefits.

On the cultural front, the lock-in scenario is characterised by cognitive and institutional inertia driven by fear of the unknown, while the leapfrog scenario is characterised by the drive to be innovative and disruptive with focus on higher and broader outcomes. Finally, on the material front, the lock-in scenario invests on rehabilitating and retrofitting existing physical infrastructure with an emphasis on optimising resource flow, while the leapfrog scenario invests on deconstructing and replacing existing physical infrastructure with a new infrastructure of a higher metabolic function.

Transformational moments are typically characterised by the increasing tension between lock-in and leapfrog scenarios in various forms. A closer look at the current tension between the oil and gas industry, which has been the dominant energy sector for more than a century, and the emerging renewable energy sector provides a clear demonstration of the above comparison at the sectoral level. Until recently, the oil and gas industry has been actively undermining the advancement of renewable energy technologies both through its covert and overt actions. As the 
build-up of the facts from climate science on the increasing adverse impact of carbon emission on the environment become indisputable, and the global consensus on climate change became stronger, the oil and gas sector started to invest in becoming a renewable energy company too. In recent years, an increasing number of major financing institutions have decided to disinvest from the use of coal for power generation and shift their investment to renewable energy development. Such moments represent a tipping point from a lock-in to a leapfrog scenario.

\section{Incidental and transformative leapfrogging}

The term 'leapfrogging' has been used in different contexts in development discourse, particularly in relation to development pathways that need to be followed by developing countries. Munasinghe (1999) and Goldemberg (2011) note that developing countries can either choose to mimic industrialised nations and undergo an economic development that is dirty, wasteful and that creates an enormous legacy of environmental pollution or to leapfrog over some of the steps of development. Some experts tend to confuse leapfrogging with a conventional process of transferring technology. Goldemberg (2011) notes that technological learning and innovation, which lead to lower costs for existing and new products and enhances productivity and competitiveness, are not synonymous with leapfrogging. The World Bank Group (2018) noted that Africa's massive infrastructure, technology, and policy gaps require disruptive solutions and thinking outside of the box, yet development policies have often been primarily programmatic and mostly incremental.

One of the critical distinctions we need to understand when we talk about leapfrogging is the distinction between an incidental leapfrogging, which is mainly incremental, and transformative leapfrogging. An incidental leapfrogging is the application and utilisation of a new generation of know-how and technology that has become available on the market as a result of externally driven innovation and operational factors. On the other hand, transformative leapfrogging is innovative and need responsive application and utilisation of a new generation of knowledge and technology for broader and transformative impacts. To illustrate with an example, the improvement of access to communication through mobile connectivity without the need to have an elaborate copper-wire based communication infrastructure for landline connectivity is a typical example of incremental leapfrogging. On the other hand, the innovative application and utilisation of the same mobile communication technology for financial inclusivity, agricultural productivity and health services to tens and hundreds of millions of people are examples of transformative leapfrogging. 
A more detailed look at the distinction between incidental and transformative leapfrogging (refer to Table 1.3) shows that the focus for incidental leapfrogging is more on acquiring the technology (hardware), while the focus for the transformative leapfrogging is on the development of a socio-technological regime that is more relevant and impactful to the specific context. In terms of the driving factors, incidental leapfrogging is mainly driven by external driving factors, which includes the availability of technology and finance, while transformative leapfrogging is primarily driven by contextually-defined and demand-driven internal factors linked to broad development objectives.

Table 1.3 Comparative analysis between incidental and transformative leapfrogging

\begin{tabular}{|l|l|l|}
\hline Key features & Incidental leapfrogging & Transformative leapfrogging \\
\hline Dominant mechanism & Diffusion of new technologies & $\begin{array}{l}\text { Development of new socio-technological } \\
\text { regimes }\end{array}$ \\
\hline Driving factors & $\begin{array}{l}\text { Mostly supply driven by external push } \\
\text { factors }\end{array}$ & $\begin{array}{l}\text { Contextually-defined and demand-driven } \\
\text { by internal factors }\end{array}$ \\
\hline Level of impact & At best segmented and incremental & Society-wide and transformative impacts \\
\hline Innovation & $\begin{array}{l}\text { Minimal innovation as the technology } \\
\text { end-user }\end{array}$ & $\begin{array}{l}\text { Unpacking of technology with a strong } \\
\text { dimension of socio-technical innovation }\end{array}$ \\
\hline Empowering potential & Higher potential of disempowering people & Provides more empowerment to society \\
\hline
\end{tabular}

In terms of its ultimate impact, incremental leapfrogging may, at best, result in segments of incremental progress that are of limited impacts, while transformative leapfrogging has high possibility to lead to society-wide and transformative impacts. In terms of innovation, incremental leapfrogging has a minimal element of innovation as it tends to focus on transferring the technology as an end-user while unpacking the technology with a purpose of enhancing the socio-technical innovation is key for transformative leapfrogging. Finally, incremental leapfrogging has high disempowering potential as it promotes dependency on providers and external players, while transformative leapfrogging empowers countries through a continuous build-up and accumulation of knowledge.

One can find a sufficient number of cases to illustrate incidental leapfrogging in all spheres of African socio-economic textures. To start with, there is very strong evidence that our education system is mostly suffering from all the malaise of incidental leapfrogging. This is because our modern education system was designed to either serve the neo-colonial governance agenda of the post-colonial era (in the field of social sciences) or feed the best and the brightest of the region's children to the economies of the developed world (through the fields of science and engineering). Hence, despite decades of effort, African education and research institutions have not been able even to identify the source of the critical development challenges that Africa is facing, let alone provide solutions for its 
underdevelopment. Overcoming these challenges would require fundamentally rebooting our knowledge system in such a way that it becomes responsive to the specific needs and demands of the respective countries.

On the technology front, there have been numerous regional and national efforts to transfer technology to African countries since the middle of the twentieth centuries. Most of our technology transfer efforts over the last five to six decades, however, have been mainly determined either by external push factors or misguided ambitions of the ruling elite. As a result, their outcome and developmental impact have been mostly marginal, and in some cases detrimental to the respective countries. As we move to the era of the Fourth Industrial Revolution (Industry 4.0), in which the role of technology is becoming exponential, the success of any country will be determined by the way it manages and utilises the opportunities from these technologies. The examples in the two boxes that follow provide insight into the benefits and damages of transformative and incremental leapfrogging respectively.

\section{Box 1.1: The case of M-Pesa, Kenya}

M-Pesa, which was launched in 2007 by Safaricom in Kenya, ignited the mobile money revolution in Africa. The service allows customers to use their mobile phones to, for example, deposit and withdraw funds from banks, make money transfers, pay bills and purchase airtime. M-Pesa's initial innovation was leapfrogging the lack of financial services by exploiting existing telecommunications infrastructure and network subscriptions in Kenya, circumventing the expenses associated with storefronts and in-cash transactions (World Bank Group, 2018). Nearly two-thirds of Kenya's adult population, which comprise a quarter of the country's GNP, use mobile payments and M-Pesa has been a lifeline for the unbanked (Brugmans, Van Dinteren \& Hajer, 2016). The service has expanded to include more advanced offerings, including ATM cash withdrawals, savings accounts, on-site retail payments, mobile ticketing for events, and corporate banking accounts. M-Pesa spawned competing mobile money services.

By 2016, 75 percent of the country's adult population had a mobile money account, with transactions amounting to the equivalent of 4.5 percent of annualised GDP per day. M-Pesa is a disruptive innovation that transformed banking in other countries, leading to an explosion of mobile money services across Africa, enhancing financial inclusion. Besides promoting inclusiveness and broader social justice, such transformative innovation makes a significant contribution to the growth of revenue and profitability of private companies. According to the annual report of Safaricom (2017), M-Pesa has become Safaricom's most significant driver of revenue growth in just a decade, contributing to over a quarter of its fiscal year 2017 revenue, with the mobile money service generating KSh 55 billion (US\$103 million).

(Sources: Safaricom, 2017:11; Brugmans, Van Dinteren \& Hajer, 2016:33) 


\section{Box 1.2: Reppie Waste-to-Energy facility, Addis Ababa, Ethiopia}

Like most of the African urban centres, Addis Ababa, which does not have a single sanitary landfill, is faced with the growing challenge of managing the domestic waste generated by its residents. The city is estimated to create 1400 tons of household waste every day. The Reppie Waste-to-Energy facility is a plant located at an open-dump site of Addis Ababa city. According to the information released during the inauguration, the plant cost about Birr 2.6 billion (approximately 95 million USD) and can generate $50 \mathrm{MW} /$ year, which could cover about 30 percent of all household electricity consumption of Addis Ababa.

The waste incineration technology that forms the basis for this project is considered to be an obsolete technology since the introduction of the programme of 'reduce, reuse and recycle' of waste in the 1990s. Furthermore, for such a facility to be operationally efficient and economically viable, it primarily needs to have a waste volume containing a significant proportion of energy-rich combustible waste. In addition, the city has to have a relatively efficient waste segregation facility, as well as a collection infrastructure that ensures collection and sorting of the waste at a minimal cost. The plant should also have a cogeneration possibility that will enable it to make use of the steam/hot water that comes out after driving the turbine.

The situation in Addis Ababa clearly shows that the city does not meet any of the above fundamental prerequisites. Actually, except for a couple of towns in South Africa, none of the urban centres in sub-Saharan Africa would fulfil any of the three operational requirements. Even those cities that may have a higher percentage of combustible waste can make higher values through recycling and re-using rather than incinerating the waste for energy generation. Considering the composition of the domestic waste of African urban centres, which is mostly (60-75 percent) dirt and biodegradable debris, burning of household waste for energy generation is a fundamentally wrong and is a misplaced choice of technology for the region.

The decision to invest in this facility has all the hallmarks for an incremental leapfrogging that is driven by external factors. It is a sunk investment that resulted in an infrastructural lock-in with significant financial consequences for decades to come.

(Source: Adapted from Mebratu, 2018)

The two cases clearly show how Africa can either achieve a more transformative outcome through an innovative application of an emerging technology or get trapped in a detrimental infrastructural lock-in by acquiring an obsolete technology as a result of submitting to external drivers. Ill-informed investment decisions made by African countries on major infrastructure may trap these countries with a significant volume of stranded assets that would have substantial operational and decommissioning costs besides the attendant social and environmental cost. The only way African countries can avoid such unsustainable scenarios is through active and strategic measures that favour transformative leapfrogging, which is needed responsive and internally driven, over incidental leapfrogging, which is supplyoriented and externally driven. 


\section{Drivers and factors of transformative leapfrogging}

Transformative leapfrogging is part of a broader transformational process that happens within a given socio-economic system. The nature of such a transformational process is mainly defined by some major driving factors that have their own dynamics, while the paths that are to be followed are determined by the specific elements of the socio-economic system under consideration. The unprecedented global economic growth witnessed since the middle of the twentieth century resulted in significant improvement in human wellbeing as seen in key human development indicators. However, it also resulted in a substantial rise of environmental pollution, natural resource degradation and widening income inequality both within and between countries. The ecological and social challenges faced by the global community continued to build up over the last couple of decades leading to an unprecedented confluence of economic, environmental and social challenges. This led to a broader recognition of the need for a transformational process at a global level, which resulted in the adoption of Agenda 2030 on Sustainable Development Goals and the Paris Agreement on Climate Change. The following are some of the critical global drivers that necessitate the transition to an inclusive, low-carbon and resource-efficient economy and provide the basis for transformative leapfrogging:

Environmental drivers: From a systems perspective, the relation between the natural and socio-economic systems is defined by the source function, which includes the provision of required resource inputs, and the sink function, which consists of the regulating function of the natural system (Mebratu, 2000). From a source function perspective, annual extraction of natural resources grew from 7 billion tons in 1900 to 60 billion tons in 2010 and, with the Business as Usual $(\mathrm{BaU})$ scenario, this is projected to reach 140 billion tons by 2050 (United Nations Environment Programme [UNEP], 2012:15). According to IPCC (2014), keeping global warming within $2^{\circ} \mathrm{C}$ would require limiting global $\mathrm{CO}_{2}$ emission at $47 \mathrm{GTCO}_{2}$ e by 2025 , which is about the level of $\mathrm{CO}_{2}$ by 2010, and reduce it to $22 \mathrm{GTCO}_{2} \mathrm{e}$ by 2050 . However, according to the Emissions Gap Report 2014 produced UNEP, greenhouse gas (GHG) emission is expected to grow to an average of $68 \mathrm{GTCO}_{2} \mathrm{e}$ by 2030 and $87 \mathrm{GTCO}_{2} \mathrm{e}$ by 2050 under the current development scenario (UNEP, 2014).

Economic drivers: Based on comprehensive economic data, Picketty (2014) showed that the economic development of the last two centuries has led to wider economic inequalities even in most developed economies. This has demonstrated the complete failure of the trickle-down theory of neo-liberal economists. He further noted that the inimical economic recession faced by almost all of the major OECD countries as a result of the economic and 
financial crisis of 2008, which is dubbed as the 'Great Recession', indicates the urgent need for transforming the global economy. The failure of neo-classical economics that takes growth in GDP as the primary measure for economic development has been increasingly recognised in the last decade.

Social drivers: The two major factors underlying the social driver are the issue of widening social inequality and job creation. Oxfam (2016) declares that, just 62 individuals had the same wealth as 3.6 billion people in 2015, which is the bottom half of humanity. According to the International Labour Organization (ILO), global unemployment reached 197.1 million, 27 million higher than in 2007 (ILO, 2016). More disturbingly, vulnerable employment reached 1.5 billion people or over 46 percent of the total employment. Coming to the specific case of inequality in resource consumption, the average use of resources in some developed countries is as high as 30 to 40 tonnes/person/ year compared to two tonnes/person/year for some developing countries (IRP, 2019). An average citizen in a developed country uses each year nearly 12 times as much energy as one would in a developing country.

Technological drivers: Technological progress made in the last couple of decades has created new opportunities and challenges that may fundamentally reshape the currently dominant global economy. The progress made in ICT has created significant transformational opportunities that empower individuals with information and knowledge. On the other hand, the increasing application of artificial intelligence (AI) in the industrial sector is a source of major threats as much as it is a source of opportunities. Progress made in areas such as materials science and engineering and nanotechnologies have also created new opportunities and challenges.

Energy drivers: Since time immemorial, the provision of energy has been at the centre of all major social transformations. Notable among these were the discovery of fire, bioenergy, coal and petroleum, which were the main drivers for the advent of sedentary settlements, agricultural revolution and industrial revolutions respectively. As noted in the Paris Agreement and Agenda 2030, it is urgent that we move to a low-carbon economy to help reduce the impact of climate change. From a social development perspective, addressing the widespread energy poverty across developing countries is a fundamental prerequisite for achieving poverty eradication. In this regard, the transition to an inclusive, low-carbon and resource-efficient society shall be driven by increasing share of renewable energy resources in national economies. This development would make renewable energy resources the next energy frontiers of this century. 
Political drivers: The currently dominant nation-state governance that is based on the principle of electoral democracy together with the global governance structure that emerged after the Second World War have been instrumental for the fastest economic growth witnessed in human history. However, it has also led to systemic governance failure that subjected billions to absolute poverty and created environmental damages of global proportion. This systemic governance failure is expressed in increasing level of public discontent and dissatisfaction that manifest themselves in civil conflicts and political unrests across the world. Addressing this challenge would require a transition towards participatory development governance that empowers people and local communities in determining and shaping their future.

Coming to the specific case of Africa, after decades of decline and stagnation, economies of African countries showed significant turnaround towards positive economic growth around the turn of the twenty-first century. Once written off as a continent uniquely suffering from structural impediments to economic growth and development, there is now widening optimism about the future of the continent (United Nations Economic Commission for Africa [UNECA], 2016). The talk of the 'doomed continent' and 'African growth tragedy' are now being replaced by metaphors such as the 'Rising continent' and the 'African lions' respectively. The African Development Report concludes that Africa's growth momentum in the past 25 years has been remarkable by historical standards. The report further states that in at least two-thirds of the African countries with data, per capita income rose for eight consecutive years between 1950-2016 at a rate of 3.5 percent per year or more (African Development Bank [AfDB], 2018:33). According to United Nations Conference on Trade and Development (UNCTAD) 2015 statistics, annual GDP growth in Africa was 4.6 percent on average between 2000 and 2014 (cited in UNECA, 2015) making it one of the fastest-growing regions in the world. As a result of these development trends, the region has been increasingly touted as the next frontier for global economic growth and foreign direct investment (FDI).

While Africa is recognised as a continent that is on the rise, it is also faced with enormous environmental and social challenges that pose significant threats to the livelihood of its population. Despite the low level of development, the ecological footprint of the region increased by 240 percent between 1961 to 2008 and the overall carbon footprint of the region increased by eight-fold during the same four decades (AfDB \& World Wide Fund [WWF], 2012). Furthermore, the ecological footprint of most of the African countries is expected to double by 2040 under the business as usual scenario. More than 640 million Africans have no access to energy, giving an electricity access rate for African countries at just over 40 percent, which is the lowest in the world. Africa's energy potential, especially renewable 
energy, is enormous, yet only a fraction is employed. Hydropower provides around a fifth of current capacity, but not even a tenth of its potential is utilised. Similarly, the technical potential of solar, biomass, wind and geothermal energy is huge (AfDB, 2018).

In terms of job creation, between 2000 and 2008, employment in the region grew at an annual average of 2.8 percent, which is roughly half the rate of economic growth (AfDB, 2018). Despite slower economic growth, yearly employment growth increased at an average of 3.1 percent from 2009 to 2014. However, this figure was still 1.4 percentage points below average economic growth. Africa is projected to have the highest population growth of any geographical region by 2050, which will have major implications for the continent's economic development. According to UNCTAD (2018), the population of Africa is projected to increase from 1.2 billion in 2017 to 2.5 billion in 2050, while its rate of urbanisation is expected to increase from 40 percent in 2015 to 56 percent of its population in 2050. Furthermore, its youth population is forecasted to grow from 231 million in 2015 to 461 million in 2050, while its working-age population (15-64 years) is predicted to grow by 2050 .

While Africa is equally, if not more, challenged by the emerging global drivers/ pressures, including climate change, it has a unique opportunity of leapfrogging to a more inclusive, sustainable and resource-efficient society that eradicates poverty and ensures improved wellbeing to its population. The following are some of the key factors that favour Africa's leapfrogging to an inclusive, low-carbon and resource-efficient society:

Resource endowment: Despite its fragility, Africa is endowed with relatively abundant natural resources that provide a solid ecological foundation for its development. This includes the renewable energy resource of the continent.

Low lock-in inertia: Related to its early stage of development, Africa has a low lock-in inertia from unsustainable physical and institutional infrastructure. This allows the country the opportunity to develop an economic development infrastructure that is climate-resilient and resource-efficient.

Technology beneficiary: Most of the technical and technological solutions that are needed for the transition are already developed and available for use. Through an effective social innovation regime, Africa could be a primary beneficiary of these emerging and resource-efficient technologies and techniques.

Affinity to sustainability: The widely prevalent communal philosophy known as Ubuntu in southern and eastern Africa, which is based on the principle of 'I am because of who you are' and the concept of Ukama, which represents 
African culture of environmental conservation through the relations between nature, society and ancestors, give African communities better affinity to sustainability (Murove, 2009).

Even if Africa has a substantial leapfrogging potential, changing this potential into a transformational opportunity would require various levels of innovations at the countries level. The World Bank Group (2018) noted that embracing and leveraging innovation and building the momentum to leapfrog will be critical for Africa to create the jobs its youth so desperately need. The Africa 2063 Agenda, endorsed by the African Union Summit in 2015, expresses the collective aspiration of African countries to further promote sustainable development of the region. It is now a matter of creating the required innovation space for countries and its people to be active economic players and contributors to the twenty-first century. Africa has mostly missed out on benefiting from the industrial revolution of the twentieth century. It cannot afford to miss out on the economic transformation of the twenty-first century.

\section{Transformative leapfrogging to wellbeing economy}

The preceding section highlighted the critical importance of focusing on transformative leapfrogging for African countries not to be left out and to secure their share of benefit from the Fourth Industrial Revolution. This section focuses on describing the macro-economic context that facilitates transformative leapfrogging in Africa and highlights the specific issues that African countries need to consider to have an effective transformative leapfrogging.

\section{The macro-economic argument}

Transformational changes happen when the organising principles of an existing system persistently fail to address existing and emerging challenges and an alternative organising principle emerges as a basis for a systemic transition. There has been a growing consensus over the last couple of decades which indicated that the organising principle of the self-regulating market, as dictated by the neoliberal economic thinking, has persistently failed. This failure has been manifested through the numerous socio-economic and socio-ecological challenges faced across the world that have become increasingly complex both in scope and frequency. American economist Joseph E. Stiglitz writes:

The current situation reminds me of the world some seventy years ago. As the world plummeted into the Great Depression, advocates of the free market said that 'Not to worry; markets are self-regulating, and given time, economic prosperity will resume.' Never mind the misery of those whose lives are destroyed waiting for this so-called eventuality. (Stiglitz, 2002:249) 
Piketty concluded:

[A] market economy based on private property, if left for itself, contains powerful forces of convergence, associated in particular with the diffusion of knowledge and skills; but it also contains powerful forces of divergence, which are potentially threatening to democratic societies and to the values of social justice on which they are based. (Piketty, 2014:571)

There have been many attempts made by various groups and institutions over the years to provide alternative organising principles for the global economic system. These attempts can be broadly categorised under the following three groups:

The first group consists of those schools of thought that consider market forces as the most efficient and effective organising principles for economic growth and prosperity and deploy macro-economic instruments to address environmental externalities. This covers the various schools of environmental economics that attempted to provide market-based solutions to environmental pollution and degradation problems while having neo-liberal economics as its foundation.

The second group consists of those schools of thought that recognise the exclusion of the inputs and services obtained from the natural ecosystem in the overall economic calculation and attempt to rectify this limitation by putting a market value on natural resources. This covers the various schools of ecological economics that gave rise to multiple shades and colours of economies, including Green Economy, Blue Economy, etc.

The third group, which is the most recent and still an emerging one, consists of those schools of thought that recognise the fundamental deficiency of the currently dominant organising principle of the neo-liberal schools of thought and advocate the need for a more transformational organising principle. This has given rise to more transformational economic models for continuous fulfilment of human wellbeing, while maintaining a healthy ecosystem as its foundation.

One of the emerging schools of thoughts that are based on recognising the critical importance of a transformational change is the concept of wellbeing economy. For this chapter, we will focus on the concept of wellbeing economy, which is recognised as the more transformational school of thought that belongs to the third group. Fioramonti (2017) notes that societies have adopted a narrow definition of economic growth as the route to development for the past couple of centuries thereby making the economy the most fundamental decision-making system in contemporary societies. He further notes that the transition from a growth economy that overemphasises the primary importance of large corporations 
to wellbeing economy that emphasises the critical role of distributed economy networks at the local level is imperative.

Table 1.4 shows some of the major distinctions between growth and wellbeing economies based on a comparison of some of the key features.

Table 1.4 Comparison between a growth economy and a wellbeing economy

\begin{tabular}{|l|l|l|}
\hline Key features & Growth economy & Wellbeing economy \\
\hline Organising principle & Linear, extractive and isolated & Circular, adaptable and integrated \\
\hline Primary drivers & Large corporations & Distributed economy networks \\
\hline Natural ecosystems & Unlimited Providers of input & $\begin{array}{l}\text { Provider of ecosystem services as the } \\
\text { foundation for the economy }\end{array}$ \\
\hline Primary measurement & Gross domestic product & Wellbeing improvement/gross happiness \\
\hline Distributional outcome & $\begin{array}{l}\text { Concentration of wealth under a } \\
\text { few corporate companies }\end{array}$ & $\begin{array}{l}\text { Inclusive economic opportunity across } \\
\text { communities }\end{array}$ \\
\hline
\end{tabular}

To start with the major organising principles, the growth economy is organised as a linear economic system that is primarily based on the extraction of inputs, production, consumption and disposal structure that concentrates economic power. Conversely, a wellbeing economy strives to develop a circular economy that is adaptable and integrated with the local community and the natural ecosystems. Similarly, a growth economy takes large corporations as the major driver of development and prosperity, while a wellbeing economy considers distributed economy networks as the primary drivers. Concerning natural ecosystems, a growth economy is the unlimited provider of inputs and services, while a wellbeing economy takes the wellbeing of the ecosystem as the essential foundation for economic development and prosperity.

The most important distinction between growth and wellbeing economies is their position on the role of gross domestic product in measuring economic progress. One of the major successes of neo-liberal economics during the second half of the twentieth century was their success in elevating growth in GDP as the ultimate measurement of economic development by countries. While recognising the specific role of GDP as a measure for economic productivity, wellbeing economics recognises the limitation of GDP as the primary measurement for development and advocates for alternative indicators that measure the wellbeing of people and the natural ecosystem. Finally, from a distributional justice perspective, a growth economy primarily results in the concentration of wealth in the hands of the few as a result of its exclusionary structure, while wellbeing economy aims at creating an inclusive economic opportunity to all members of the community.

In a nutshell, a wellbeing economy is an economy that strives for continuous fulfilment of basic human needs and aspirations of its people within the limits 
and possibilities of its resource and available external opportunities. As noted by Swilling and Annecke (2012), a sustainable society must be both equitable in social terms and more respectful of the fact that human survival depends on the natural systems that have emerged from the evolutionary process. This would require deploying a national development strategy that is home-grown and organic but at the same time adaptive to the global dynamics. It also involves governance mechanisms that are equipped with transformative leadership based on adaptive learning and inclusivity. A wellbeing economy addresses both distributive and participatory justice of its people through their active involvement in the planning and management of the development process. Progress towards a wellbeing economy is measured by an actual and perceived improvement in the wellbeing of its people rather than solely relying on growth rate in GDP and FDI.

For most developing countries, progress towards a wellbeing economy requires the development of distributed local economy networks in combination with low-carbon and resource-efficient national backbone industries. The primary operational objectives of the distributed economy would be the creation of jobs and adding of value at the local level, which are extremely crucial for African countries. Such an economy also recognises the critical importance of maintaining the wellbeing of the natural ecosystem as the foundation for the fulfilment of its developmental objectives on a sustainable basis. In essence, a wellbeing economy provides a fundamentally new vehicle for the effective implementation of Agenda 2030 on sustainable development goals with a qualitatively higher outcome.

\section{The foundations for transformative leapfrogging}

Tan, Ng and Jiang (2018) concluded that the process of technology Leapfrogging is analogous to the mechanics of a physical leapfrog and traverses across four stages: psyching, planting, propelling, and perpetuating. The psyching stage primarily covers the broad institutional framework that is required for a transformative leapfrogging. The planting stage focuses on establishing the foundation upon which the leapfrogging will be grounded. The propelling stage is the stage at which the technological leapfrogging is actualised, while the perpetuating stage is the stage at which the transformative impact of the leapfrogging process results in a new trajectory of development with multiple benefits. Taking the four stages of leapfrogging as a basis, Table 1.5 presents the key features and related outcomes of actions taken at the different stages of leapfrogging. 
Table 1.5 Cycles of transformative leapfrogging

\begin{tabular}{|c|c|c|c|}
\hline Stages & Focus & Mechanisms & Outcomes \\
\hline Psyching & $\begin{array}{l}\text { Developing a strategic } \\
\text { framework aligned with } \\
\text { national development } \\
\text { goals }\end{array}$ & $\begin{array}{l}\text { - Defining clear strategic } \\
\text { objectives } \\
\text { - Translating it into concrete } \\
\text { action plans }\end{array}$ & $\begin{array}{l}\text { - Clarity of vision and commitment } \\
\text { - Platform for collaborative actions }\end{array}$ \\
\hline Planting & $\begin{array}{l}\text { Building the foundation } \\
\text { for leapfrogging }\end{array}$ & $\begin{array}{l}\text { - Defining the partnership } \\
\text { modality with external } \\
\text { partners } \\
\text { - Developing the required } \\
\text { local skillsets }\end{array}$ & $\begin{array}{l}\text { - Repurposing of existing capacity } \\
\text { and creating new ones } \\
\text { - Establishment of an } \\
\text { organisational anchor for the } \\
\text { leapfrogging process }\end{array}$ \\
\hline Propelling & $\begin{array}{l}\text { Actualising the } \\
\text { leapfrogging process }\end{array}$ & $\begin{array}{l}\text { - Choosing the right set of } \\
\text { technologies } \\
\text { - Contextualization of } \\
\text { technologies to local needs }\end{array}$ & $\begin{array}{l}\text { - Innovative application of acquired } \\
\text { technologies } \\
\text { - Effective assimilation of } \\
\text { transferred technologies }\end{array}$ \\
\hline Perpetuating & $\begin{array}{l}\text { Consolidating } \\
\text { the trajectory for } \\
\text { transformative change }\end{array}$ & $\begin{array}{l}\text { - Leveraging the symbiotic } \\
\text { impact } \\
\text { - Consolidating the path- } \\
\text { dependent gains }\end{array}$ & $\begin{array}{l}\text { - Optimising the transformative } \\
\text { impact } \\
\text { - Setting the scene for the next } \\
\text { leapfrogging }\end{array}$ \\
\hline
\end{tabular}

The first stage of the transformative leapfrogging cycle is the psyching stage, which involves developing a strategic technology framework aligned with national development goals that provide clarity on the vision and commitment of the government and create the platform for collaborative actions between the key stakeholders. This has to be followed by definition of the partnership modality both within and outside the country and development of the required skillsets. This may include repurposing of existing capacity and building new ability to cover for the gaps and could also lead to the emergence of organisational anchors for the leapfrogging process. The propelling stage, which is about actualising the leapfrogging process, involves choosing the right set of technologies and contextualising them to local conditions and needs. This will, in turn, lead to the innovative application of acquired technologies and effective assimilation of transferred technologies. The final stage of perpetuating is about consolidating the trajectory for transformative change by leveraging the symbiotic impact of the transferred technology and enhancing the path-dependent gains. Moreover, the process at this stage sets the scene for the next phase of leapfrogging.

\section{Strategic considerations}

For Africa to realise its leapfrogging potential and benefit effectively from the global transition, it needs to be more innovative and follow an alternative economic development path that takes into account the global drivers of change and the specific leapfrogging opportunity of the region. The critical factor that determines the ability of African countries to gain the maximum benefit from the existing leapfrogging opportunity is the strategic choice and decisions they make in building their socio-economic infrastructure for the coming decades. 
Figure 1.2 shows the key features of transformative infrastructure.

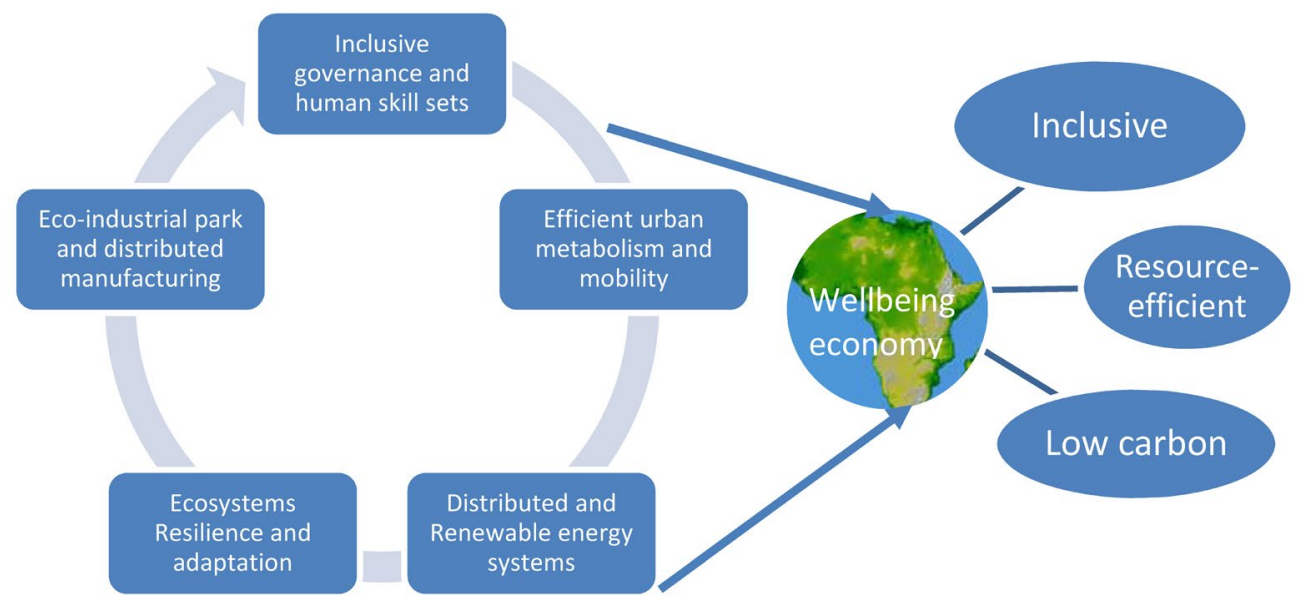

Figure 1.2 Key features of transformative infrastructure

The following are the key strategic areas that need to be given primary attention by all African countries to lay the foundation for the transition to a more inclusive, low-carbon and resource-efficient society:

Ecological infrastructure: Africa's possibility for its development on a sustainable basis and the future of its people for the coming decade depends mainly on its ability to manage and effectively utilise its natural resource base as the foundation for its economic development. Building the adaptive capacity of local communities and enhancing the resilience of the natural ecosystem is particularly critical in light of the growing threat from climate change and the pressure from a high rate of population growth.

Energy infrastructure: The transition in energy systems is one of the critical determinants of the progress towards an inclusive, low-carbon and resourceefficient economy. According to the African Progress Panel (APP), the first step that needs to be taken by each African country in this regard is ensuring the transition to sustainable energy systems in which renewable energy resources shall form the core of the energy infrastructure (APP, 2016). Besides the resource mix, the smart combination between grid and off-grid distributed energy systems will be a crucial factor for ensuring the distributive impact of the energy system. The latter aspect is particularly critical for most countries in Africa as it plays a key role in promoting energy access and poverty eradication through inclusive socio-economic development at the local level. 
Industrial infrastructure: An efficient transformation of finite natural resources through industrial processing is a fundamental prerequisite to meet the basic needs of a growing global population. However, such efficient conversion requires replacing the predominantly linear mode of industrial production with an industrial infrastructure that promotes a circular economy. The United Nations Industrial Development Organization (UNIDO) maintains that a key component of such infrastructure is the development of eco-industrial parks as the backbone of industrialisation (UNIDO, 2016). Furthermore, concerted planning efforts should be made to enhance the productive capacity of local communities as part of a sustainable value chain by effectively linking the development of distributive energy systems with value addition at the local level.

Urban infrastructure: The development of urban infrastructure to facilitate effective and efficient flow and movement of resources and promote the development of socio-economically productive urban centres is another crucial factor of leapfrogging in Africa. Besides developing multi-modal urbanisation strategy that effectively manages the push and pull factors of urbanisation, countries need to utilise the transformational contribution of progress in ICT and renewable energy development to facilitate productive empowerment of local communities.

Human resource: Realising all the opportunities that are highlighted earlier and utilising the full potential of the region can only happen if countries have a working force that is equipped with the right set of skills and capability. This would require re-orienting existing education and training programmes by incorporating a new set of knowledge and skills that are necessary for the transformational change. The new set of skills and knowledge needs to be channelled towards promoting innovation at all levels of the society with a particular emphasis given to social innovation on which there is a significant gap.

In general, the global community is faced with a moment of another major social transformation in human history and Africa is uniquely positioned to lead this transformational process provided that it seizes the emerging leapfrogging opportunity. This requires effectively utilising the development possibilities that are created by key transformation drivers such as recent developments in renewable energy development and the changes driven by the development of information and communication technology. The progress to be made by African countries in this leapfrogging process will largely be determined by their success in creating the required physical and knowledge infrastructures for the transition to an inclusive, low-carbon and resource-efficient economies. 


\section{Conclusion}

The Sustainable Development Goals of Agenda 2030 and the Paris Declaration on Climate Change coupled with the emerging possibilities from the development in renewable energy and IT-based technologies have created new opportunities for African countries to transition to inclusive, low-carbon and resource-efficient economies. Capturing and utilising these opportunities will largely depend on the ability of countries to develop transformational infrastructure that promotes the development of a wellbeing economy, which provides a strong basis for fulfilling the aspirations of Agenda 2063: The Africa We Want. The following are the key issues that need to be considered by national governments, development financing institutions and international development partners as the primary drivers of infrastructure development in African countries:

1. National governments: need to strategically focus on transformative leapfrogging that is contextually relevant and internally driven rather than being passive recipients of incidental leapfrogging that is driven by external interest and influence. This will provide them with a strong basis to make the right investment decisions and technology selections that result in transformational infrastructure that promotes the wellbeing of their people on a sustainable basis.

2. Development financing institutions need to desist from pushing and promoting conventional infrastructure development that is unsustainable and economically and socially inefficient in the name of development financing. Instead, they need to assist and support African countries to leapfrog into transformational infrastructure that is low-carbon and resource-efficient while at the same time promote socially inclusive development that benefits current and future generation.

3. International development partners, including the United Nations system and bilateral development organisation, need to support building the capacity of African countries in managing the transition to inclusive, climate-resilient and resource-efficient economies. It is essential to recognise that getting Africa on a more sustainable development trajectory will significantly determine the success of the global effort on mitigating the effect of climate change and the progress towards global sustainability.

In this opening chapter to the book, a modest attempt is made to lay down the basis for a new development narrative with emphasis on transformational infrastructure development. It is hoped that this will be further enriched through lessons to be gained from the concrete actions that African countries will take in the coming years and decades. 


\section{References}

Africa Progress Panel. (2016). Power, people and planet: Seizing Africa's energy and climate opportunity. Geneva: APP.

African Development Bank. (2018). African economic outlook 2018. Abidjan: AfDB.

African Development Bank \& World Wide Fund for Nature. (2012). African ecological footprint: Greening Africa's ecological infrastructure. Geneva: AfDB and WWF.

Brugmans, G., van Dinteren, J.V. \& Hajer, M. (Eds). (2016). The next economy: IABR 2016. IABR exhibition catalogue. Rotterdam: The International Architecture Biennale Rotterdam.

Corvellec, H., Campos, M.J. \& Zapata, P. (2012). Infrastructures, lock-in, and sustainable urban development: The case of waste incineration in the Göteburg Metropolitan Area. Journal of Cleaner Production 50(1): 32-39. https://doi. org/10.1016/j.jclepro.2012.12.009

Cowan, R. \& Hulten, S. (1996). Escaping lock-in: The case of the electric vehicle. Technological Forecasting and Social Changes 53(1): 61-79. https://doi. org/10.1016/0040-1625(96)00059-5

Fioramonti, L. (2017). Wellbeing economy: Success in a world without growth. Johannesburg: Macmillan.

Fudenberg, D., Gilbert, R., Stiglitz, J. \& Tirole, J. (1983). Preemption, leapfrogging, and competition in patent races. European Economic Review 22(1): 3-31. https://doi. org/10.1016/0014-2921(83)90087-9

Goldemberg, J. (2011). Technological leapfrogging in the developing world. Georgetown Journal of International Affairs 12(1) (Winter/ Spring 2011): 135-141. https://doi. org/10.1524/9783486709612.135

Gottlieb R.S. (Ed.). (1996). This sacred earth: Religion, nature and environment. New York: Routledge.
Grabher, G. (Ed.). (1993). The embedded firm: On the socioeconomics of industrial networks. London: Routledge.

International Bank for Reconstruction and Development. (1992). World development report 1992. Washington, DC: World Bank

International Labour organization. (2016). World employment social outlook: Trends in 2016. Geneva: ILO. https://doi. org/10.1002/wow3.76

International Panel on Climate Change. (2014). Climate change synthesis report. Geneva: IPCC. https://doi.org/10.1017/ CBO9781107415416

International Resource Panel. (2019). Global resource outlook: Natural resources for the future we want. Nairobi: UNEP.

Liebowitz, S.J. \& Margolis, S.E. (1995). Pathdependence, lock-in, and history. Journal of Law, Economics and Organization 11(1): 205-226. https://doi.org/10.2139/ ssrn. 1706450

Meadows, D., Meadows, D. \& Randers, J. (1992). Beyond the limits. London: Earthscan Publications.

Mebratu, D. (1998). Sustainability and sustainable development: Historical and conceptual review. Environmental Impact Assessment Review 18(6): 493-520. https:// doi.org/10.1016/S0195-9255(98)00019-5

Mebratu, D. (2000). Strategies for sustainable industrial development in sub-Saharan Africa. $\mathrm{PhD}$ dissertation, Lund University.

Mebratu, D. (2018). Repi waste-to-energy plant: Sunk, misguided. https://bit. ly/2ODitn4 [Accessed 12 September 2019].

Munasinghe, M. (1999). Is environmental degradation an inevitable consequence of economic growth: Tunneling through the Kuznets curve. Ecological Economics 29(1): 89-109. https://doi.org/10.1016/S09218009(98)00062-7 
Murove, M.F. (Ed.). (2009). African ethics: An anthology of comparative and applied ethics. Pietermaritzburg, South Africa: University of KwaZulu-Natal Press.

Nelson, R. \& Nelson, K. (2002). Technology, institutions, and innovation systems. Research Policy 31(2): 265-272. https:// doi.org/10.1016/S0048-7333(01)00140-8

Oxfam. (2016). An economy for 1\%: How privilege and power in the economy drive extreme inequality and how this can be stopped. London: Oxfam.

Padilla, E. (2017). What can developing countries gain from a green transformation? In: T. Altenburg \& C. Assmann (Eds), Green industrial policy. Concept, policies, country experiences. Geneva, Bonn: UN Environment; German Development Institute / Deutsches Institut für Entwicklungspolitk (DIE).

Piketty, T. (2014). Capital in the twenty-first century. Cambridge, MA: The Belknap Press of Harvard University Press. https:// doi.org/10.4159/9780674369542

Safaricom. (2017). Safaricom annual report and financial statements 2017. https://bit. ly/2VBC0Wp [Accessed 18 May 2018].

Schreyögg, G. \& Sydow, J. (Eds). (2010). The bidden dynamics of path dependence: Institutions and Organizations. Basingstoke, UK: Palgrave Macmillan. https://doi. org/10.1057/9780230274075

Schumpeter, J. (1942). Capitalism, socialism and democracy. New York: Harper.

Shafik, N. (1994). Economic development and environmental quality: An econometric analysis. Oxford Economic Papers 46 (October): 757-773. https://doi. org/10.1093/oep/46.Supplement_1.757

Sidak, J.G. \& Teece, D.J. (2009). Dynamic competition in antitrust law. Journal of Competition Law \& Economics 5(4): 581-631. https://doi.org/10.1093/joclec/ nhp024
Stern, D. (2003). The environmental Kuznets curve. International Society for Ecological Economics Internet Encyclopedia of Ecological Economics. https://bit.ly/2OJcBbQ [Accessed 12 September 2019].

Stiglitz, J. (2002). Globalisation and it's discontent. London: Penguin Books.

Swilling, M. \& Annecke, E. (2012). Just transitions: Explorations of sustainability in an unfair world. Tokyo: United Nations University.

Tan, B., Ng, E. \& Jiang, J. (2018). The process of technology leapfrogging: Case analysis of the national ICT infrastructure development journey of Azerbaijan. International Journal of Information Management 38(1): 311-316.

Tirole, J. (1988). The theory of industrial organization. Cambridge: MA: MIT Press.

United Nations Economic Commission for Africa. (2016). Transformative industrial policy for Africa. Addis Ababa: United Nations Economic Commission for Africa.

United Nations Environment Programme. (2012). Responsible resource management for a sustainable world: Findings from the International Resource Panel. Nairobi: UNEP.

United Nations Environment Programme. (2014). The emissions gap report 2014. Nairobi: UNEP. https://doi. org/10.18356/988ece44-en

United Nations Industrial Development Organization. (2016). Global assessment of eco-industrial parks in developing and emerging countries. Vienna: UNIDO.

World Bank Group. (2018). Leapfrogging: The key for Africa's development. Washington, DC: World Bank. 